\title{
The impact of social grant dependency on smallholder maize producers' market participation in South Africa: Application of the double-hurdle model
}

\begin{tabular}{|c|c|}
\hline \multicolumn{2}{|c|}{$\begin{array}{l}\text { Authors: } \\
\text { Sikhulumile Sinyolo } 1 \text { (1) } \\
\text { Maxwell Mudhara } \\
\text { Edilegnaw Wale }{ }^{2}\end{array}$} \\
\hline \multicolumn{2}{|c|}{$\begin{array}{l}\text { Affiliations: } \\
{ }^{1} \text { Economic Performance and } \\
\text { Development, Human } \\
\text { Sciences Research Council, } \\
\text { South Africa }\end{array}$} \\
\hline \multicolumn{2}{|c|}{$\begin{array}{l}{ }^{2} \text { Discipline of Agricultural } \\
\text { Economics, University of } \\
\text { KwaZulu-Natal, South Africa }\end{array}$} \\
\hline \multicolumn{2}{|c|}{$\begin{array}{l}\text { Corresponding author: } \\
\text { Sikhulumile Sinyolo, } \\
\text { sksinyolo@gmail.com }\end{array}$} \\
\hline \multicolumn{2}{|c|}{$\begin{array}{l}\text { Dates: } \\
\text { Received: } 09 \text { Sept. } 2015 \\
\text { Accepted: } 23 \text { Mar. } 2017 \\
\text { Published: } 26 \text { May } 2017\end{array}$} \\
\hline \multicolumn{2}{|c|}{$\begin{array}{l}\text { How to cite this article: } \\
\text { Sinyolo, S., Mudhara, M. \& } \\
\text { Wale, E., 2017, 'The impact of } \\
\text { social grant dependency on } \\
\text { smallholder maize producers' } \\
\text { market participation in South } \\
\text { Africa: Application of the } \\
\text { double-hurdle model', South } \\
\text { African Journal of Economic } \\
\text { and Management Sciences } \\
\text { 20(1), a1474. https://doi. } \\
\text { org/10.4102/sajems. } \\
\text { v20i1.1474 }\end{array}$} \\
\hline \multicolumn{2}{|c|}{$\begin{array}{l}\text { Copyright: } \\
\text { (C) 2017. The Authors. } \\
\text { Licensee: AOSIS. This } \\
\text { is licensed under the } \\
\text { Creative Commons } \\
\text { Attribution License. }\end{array}$} \\
\hline \multicolumn{2}{|l|}{ Read online: } \\
\hline 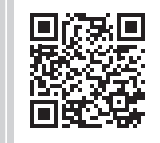 & $\begin{array}{l}\text { Scan this QR } \\
\text { code with your } \\
\text { smart phone or } \\
\text { mobile device } \\
\text { to read online. }\end{array}$ \\
\hline
\end{tabular}

Background: Social grants have become an increasingly popular means of improving the welfare of poor households in South Africa and beyond. While the goals of these transfers are to alleviate current poverty as well as to improve human capital capacity, they also have unintended effects, positive or negative, on beneficiary households. A question that has not been adequately addressed in the literature is the role that social grants play in the efforts to commercialise smallholder farming.

Aim: The aim of this study was to examine the impact of social grant dependency on the incentives of smallholder maize producers to participate in the market.

Setting: The study was done in the rural areas of four districts (Harry Gwala, Umzinyathi, Umkhanyakude and Uthukela) in the KwaZulu-Natal province, South Africa.

Methods: The study adopted a quantitative research design. A total of 984 households were randomly selected from the four districts, of which 774 had planted maize in the previous season. The analysis was done on the 774 farmers who had planted maize. The double-hurdle model was used for statistical analysis.

Results: The results show a negative association between social grant dependency and market participation, suggesting that social grant-dependent households are more subsistent, producing less marketable surplus. Moreover, households with access to social grants sold less quantities of maize in the market, indicating reduced selling incentives.

Conclusion: The study indicates that social grants reduce the incentives of smallholder farmers to commercialise their production activities. The results suggest that, while policies aimed at reducing transaction costs would increase smallholder market participation, attention should be paid on how to reduce social grants' dis-incentive effects. To reduce spill over effects to unintended household members, the study recommends offering part of the grant as 'in-kind support', which is specific to the intended individual beneficiary.

\section{Introduction}

There is a general consensus in the literature (e.g. Alene et al. 2008; Barrett \& Swallow 2006; Carter \& Barrett 2006; De Janvry, Fafchamps \& Sadoulet 1991; Von Braun 1995) that promoting smallholder market participation is an important pathway towards poverty reduction, economic growth and development in developing countries. It has been argued that smallholder agriculture would contribute more to rural livelihoods if it breaks out of the subsistence trap into commercial agricultural production (Barrett \& Swallow 2006; Hazell et al. 2010). As a result, the transition from semi-subsistence to commercialised agriculture has been a core theme of rural development initiatives for many years across the developing countries (Agwu, Anyanwu \& Mendie 2012; Barrett 2008).

This also applies to South Africa, which, on the one hand, is characterised by large-scale producers well connected to markets and, on the other hand, has a smallholder farming sector that is unprofitable and is characterised by weak links to markets (Makhura, Kirsten \& Delgado 2001; Ortmann \& King 2010; Van der Heijden \& Vink 2013). The general view is that smallholder farmers' market participation should be improved to reduce rural poverty and household food insecurity in South Africa (Chikazunga 2013; Khumalo 2013; Senyolo et al. 2009). Moreover, the high unemployment rates and limited prospects for labour absorption in the non-farm sector have led the South African government to prioritise the expansion of the smallholder sector as part of its broader job creation strategy [Aliber \& Hall 2012; National Planning Commission (NPC) 
2012]. According to Aliber and Hall (2012), an important element of such a strategy is that it should promote the graduation of subsistence producers so that they can earn an income as commercial smallholder producers.

Accordingly, the South African government has identified increased commercialisation of smallholder farming as key in reducing rural poverty as well as stimulating rural economic development [Department of Agriculture, Forestry and Fisheries (DAFF) 2012; NPC 2012]. For example, the New Growth Path sets target of establishing 300000 additional market-oriented smallholder producers by 2020 [Department of Economic Development (DED) 2011]. In line with these targets, the DAFF has been implementing the Strategic Plan for Smallholder Support (SPSS), aimed at supporting the smallholder farmers to graduate to commercial status (DAFF 2012). Despite the concerted government efforts in the past, smallholder farmers' market participation has not significantly improved in South Africa (Hlongwane, Ledwaba \& Belete 2014).

A range of constraints and barriers reducing smallholder producers' market participation levels have been identified, with most of the studies highlighting the negative impact of transaction costs in this regard (Biénabe \& Vermeulen 2011; Hlongwane et al. 2014; Jari \& Fraser 2013; Makhura 2001; Van der Heijden \& Vink 2013). However, the question that has not been adequately addressed is the impact of social grants on the incentives of smallholder farmers to commercialise their production activities. South Africa has social grants that benefited an average of over 16 million of the poor each month in 2014 (South Africa Social Security Agency 2014). Most smallholder farming households are beneficiaries of at least one of the different social grants. Even though the social grants are targeted to specific vulnerable groups such as the young, old or chronically sick among poor households, they generally benefit households as a whole (Abel 2013; Klasen \& Woolard 2008).

On the one hand, social grants can be an important complement to the smallholders' commercialisation agenda, as the extra income may relieve the credit and liquidity constraints of farm households, enabling them to overcome the transaction costs they face (Barrientos 2012; Bezu \& Holden 2008; Boone et al. 2013; Tirivayi, Knowles \& Davis 2016). On the other hand, the economic theory predicts that social grants may induce negative behavioural changes and entrench a culture of dependency and entitlement, undermining the incentives of farmers to commercialise their production activities (Barrett 2006; Devereux 2001; Gibson 2015; Lentz, Barrett \& Hoddinott 2005). The theoretical rationale is that increased household income because of unearned income like social grants, reduces the marginal benefit that households obtain from undertaking further income-generating activities such as farming (Binger \& Hoffman 1998).

Descriptive statistics and anecdotal evidence from several studies in South Africa (e.g. Aliber \& Hall 2012; Aliber \& Hart
2009; Tshuma 2012; White \& Killick 2001) have highlighted the potential negative effect of social grants on smallholder farming activities. Tshuma (2012) reported that many smallholder farmers are reducing the area under cultivation, even for subsistence purposes, as they depend more on social grants for their income. This has resulted in social grants becoming the greatest source of income for the majority of rural households in South Africa, surpassing that of smallholder agriculture by far (Tshuma 2012). However, the understanding of the linkages between smallholder market participation and social grants has not been based on in-depth empirical analyses. Recent reviews of empirical literature on the potential linkages between social cash transfers and smallholder agriculture (e.g. Bastagli et al. 2016; Tirivayi et al. 2016) have indicated that the research on the issue is currently thin and the results are of a mixed nature. Most of the studies (Boone et al. 2013; Covarrubias, Davis \& Winters 2012; Radel et al. 2016; Todd, Winters \& Hertz 2010), mainly in Latin American and sub-Saharan African (SSA) countries, evaluated the direct and indirect impact of social transfers on agriculture and focussed on agricultural outcomes such as asset accumulation, input use, output and labour allocation. While literature generally showed the positive role of social transfers in improving the productive capacity of beneficiaries, little is known about whether social cash transfers have positive or negative effects on the smallholder market participation.

Understanding the linkages between social transfers and smallholder commercialisation is important to improve the policy coherence between social protection and smallholder agriculture, as called upon in recent literature (e.g. Boone et al. 2013; FAO 2016; Tirivayi et al. 2016). Increased policy coherence would ensure that social cash transfers do not reduce the incentives for the poor to work themselves out of poverty through smallholder farming, which is the main incomegenerating activity in rural areas (Gibson 2015; Maluccio 2010). Few studies, if any, have explicitly and systematically articulated the theoretical linkage and examined the empirical relationship between the two variables in South Africa and beyond. This study, therefore, seeks to address this pertinent question by focussing on smallholder maize producers' market participation. Maize was chosen because it is the most important grain crop in South Africa, and is the main crop grown by smallholder farmers (Akpalu, Hassan \& Ringler 2010; Biénabe \& Vermeulen 2011; D’Haese et al. 2013).

The remainder of this article is organised into three sections. The next section presents the research methodology, introducing the theoretical framework, the study area, the sampling techniques adopted and the empirical models employed. The penultimate section presents results and their discussions, while the conclusions and implications for policies are contained in the final section.

\section{Research methodology Survey design and data}

The sample was randomly drawn from four purposively chosen districts across the KwaZulu-Natal (KZN) province: 
Harry Gwala, Umzinyathi, Umkhanyakude and Uthukela. These districts have a significant number of rural communities engaged in farming activities and are among the poorest in terms of average household incomes (Stats SA 2012). The KZN province is characterised by high poverty levels and lack of economic opportunities, particularly in rural areas. Social grants and smallholder farming play important roles in the livelihoods of the rural dwellers.

The lists of farmers were obtained from the extension offices of the respective districts, which also helped direct the enumerators to the selected farmers' homesteads. A total of 984 households were randomly selected from the four districts, of which 774 had planted maize in the previous season. The analysis was done on the 774 farmers who had planted maize in the last season. Data were collected between June and November 2014 using a pretested structured questionnaire. The questionnaire was administered by trained and experienced enumerators who had good knowledge of the rural farming systems and who could speak the local isiZulu language.

The questionnaire included information on basic household head characteristics, measures of household wealth endowment (such as household assets, livestock and land) and household income sources or amounts. The questionnaire also captured the crop production and marketing behaviour of the households, asking questions about types of crops the household planted in the previous season, quantities harvested and sold. Furthermore, the questionnaire captured farmers' membership to associations as well as their access to institutional support such as market access, social grants, credit and extension.

\section{Conceptual framework and variables}

The households' decision on whether or not to participate in the maize market was considered under the random utility framework (McFadden 1974) and the theory of farm household decision-making under imperfect markets (De Janvry et al. 1991). The random utility framework postulates that the smallholder maize farmers will decide to participate in the market if the perceived utility or net benefit from participation is greater than in the case without participation. The theory of farm household decision-making under imperfect markets indicates that a household's market participation is mainly a function of market transaction costs. According to De Janvry et al. (1991), market failure is household specific, not commodity-specific. This is because households who participate in the market are those with market gains that are higher than the transaction costs, while those with market gains less than the transaction costs will not participate.

Even though in some cases markets do not even exist (missing markets), the majority of the cases of market failure in developing countries are because of high transaction costs (Alene et al. 2008; De Janvry et al. 1991; Goetz 1992; Key, Sadoulet \& De Janvry 2000; Omamo 1998). In South Africa, these transaction costs are because the smallholder farmers are located in rural areas which are remote and far away from major consumers of farm products. Moreover, the rural areas are characterised by poor infrastructure, inadequate information and thin credit markets. As explained in De Janvry et al. (1991) and other recent studies (e.g. Alene et al. 2008; Mather, Boughton \& Jayne 2013), the household's market participation is influenced by its economic position and institutional environment. The model estimated in this study included proxies for transaction costs, wealth endowment and human capital. Table 1 shows the variables that were considered and their descriptions.

The table presents the household head demographics (age, gender and household size), wealth endowment (farm size, asset values, livestock size, etc.), human capital (education level and farming experience), social capital (farmer groups membership) and farmer support services (access to extension, agricultural training, credit and markets) that

TABLE 1: Variables description.

\begin{tabular}{|c|c|}
\hline Variable name & Variable description \\
\hline Maize output & Maize output harvested last season (tons) \\
\hline Maize selling & $\begin{array}{l}\text { Household sold maize in the market last season } \\
(1=\text { Yes; } 0=\text { No })\end{array}$ \\
\hline Quantity of maize sold & Quantity of maize sold (tons) \\
\hline Proportion of maize sold & Proportion of maize output sold \\
\hline Age & Household head age (Years) \\
\hline Gender & Household head gender ( $1=$ Male, $0=$ Female $)$ \\
\hline Education level & Household head education level (Years) \\
\hline Household size & Household size (Numbers) \\
\hline Maize price & Price of maize output per ton (Rands/ton) \\
\hline Land size & Land size household has access to (ha) \\
\hline Livestock size & Livestock size (TLUs) \\
\hline Asset value & Value of household assets (Rands) \\
\hline Access to grants & $\begin{array}{l}\text { Household has access to social grants } \\
(1=\text { Yes, } 0=\mathrm{No})\end{array}$ \\
\hline Number of grant beneficiaries & Number of social grant beneficiaries per household \\
\hline Total income & Annual total household income (Rands) \\
\hline Grant income & Annual income from social grants (Rands) \\
\hline Farm income & Annual income from farm activities (Rands) \\
\hline Other income & Annual income from other off-farm activities (Rands) \\
\hline Proportion of grant income & Proportion of income from social grants \\
\hline Proportion of farm income & Proportion of income from farming activities \\
\hline $\begin{array}{l}\text { Proportion of grant income } \\
\text { used in farming }\end{array}$ & Proportion of social grants income used in farming \\
\hline Extension & Access to extension ( $1=$ Yes, $0=\mathrm{No}$ ) \\
\hline Information sources & Number of information sources \\
\hline Access to market & Market access ( $1=$ Good, 0 = Poor $)$ \\
\hline Access to credit & Access to credit $(1=\mathrm{Yes}, 0=\mathrm{No})$ \\
\hline Training & Access to agricultural training $(1=\mathrm{Yes}, 0=\mathrm{No})$ \\
\hline Group membership & Farmer group member $(1=\mathrm{Yes}, 0=\mathrm{No})$ \\
\hline Distance to market & Distance to the maize market $(\mathrm{km})$ \\
\hline Farming experience & Household head farming experience (Years) \\
\hline Irrigation access & $\begin{array}{l}\text { Access to water for irrigation purposes } \\
(1=\text { Yes, } 0=\text { No })\end{array}$ \\
\hline Employment status & $\begin{array}{l}\text { Household head off-farm employment } \\
(1=\text { Yes, } 0=\text { No) }\end{array}$ \\
\hline Business ownership & $\begin{array}{l}\text { Ownership of small non-farm business } \\
(1=\text { Yes, } 0=\text { No })\end{array}$ \\
\hline Harry Gwala & District_1 $(1=$ Harry Gwala, $0=$ Otherwise $)$ \\
\hline Umzinyathi & District_2 (1 = Umzinyathi, 0 = Otherwise) \\
\hline Uthukela & District_3 ( $1=$ Uthukela, $0=$ Otherwise) \\
\hline Umkhanyakude & District_4 ( 1 = Umkhanyakude, 0 = Otherwise) \\
\hline
\end{tabular}


were included in the model. District dummies were also included to capture the district-specific attributes that result in spatial variations in the political, social and agro-climatic environment of these districts which impact market participation. The quantities of maize produce harvested and sold as well as prices were based on the recall by the farmers. Even though the individual prices the households faced were collected, the average ward price was used as an explanatory variable in the model, following previous studies such as Alene et al. (2008) and Komarek (2010). This is because if household specific prices were used, those households with zero sales would have been excluded from the analysis. Total household income included the incomes that the household received from different sources, such as employment, remittances, social grants, farming, micro-businesses, and arts and culture.

It was also hypothesised that access to social grants will have a negative effect on the smallholder market participation. This is because increased income from social grants may entrench a culture of dependency and entitlement among beneficiary households (Abel 2013; Bertrand, Mullainathan \& Miller 2003; Samson et al. 2004), reducing incentives by households to engage in income-generating activities. The influence of social grants was captured using two variables: a dummy variable showing whether or not a household has access to social grants and a proportional variable showing the contribution of social grants to total household income. The proportion variable captured the level of household dependency on social grants.

\section{The double-hurdle model}

The maize output marketing decision was modelled as a two-step decision process: (1) the household decides whether or not to participate in the market and (2) the household decides on the volume of transactions. The double-hurdle model (Cragg 1971) was used to model this two-step decision process, following several other market studies (e.g. Holloway, Barrett \& Ehui 2005; Komarek 2010; Mabuza, Ortmann \& Wale 2014; Mather et al. 2013; Ndoro, Mudhara \& Chimonyo 2014). This model was chosen over the Heckman sample selection model, which has been used by many studies (e.g. Alene et al. 2008; Bwalya, Mugisha \& Hyuha 2013; Geoffrey et al. 2013; Goetz 1992; Sebatta et al. 2014). The Heckman approach addresses the statistical challenge posed by cases in which market sales equal zero as a missing data problem. However, the issue of zero market sales does not represent missing values as a zero amount of maize output sold is a valid economic choice to be explained (Mather et al. 2013). The double-hurdle model produces more superior estimates than the Heckman model when one is dealing with true zeros (Dow \& Norton 2003).

According to the double-hurdle model, a farmer faces two hurdles while deciding on maize market participation: whether or not to participate in the market and how much maize to sell in the market. This approach distinguishes between fixed transaction costs, which influence only the first decision of participation, and variable transaction costs, which can influence both decisions (Key et al. 2000). For example, distance to the market was considered in both decision stages because farmers nearer to the market incur less information cost, thus reducing fixed costs, and they also incur lower transport costs, reducing variable costs. Similarly, association membership was considered in both stages because group members may have higher access to information as they exchange information and experience. On the other hand, individual members would incur less variable costs (transport costs and risks) as they share these with other group members. However, access to different information sources only mitigates the costs of accessing information, which are fixed costs, but not the variable transaction costs.

The double-hurdle model integrates and simultaneously estimates the probit model to determine the probability of maize market participation and the truncated normal model for the level of market participation. The binary variable of maize market participation $(\mathrm{w})$, assumed to follow a probit model, was specified as follows:

$\mathrm{P}(\mathrm{w}=1 \mid \mathrm{x})=\Phi(\mathrm{x} \gamma)$

[Eqn 1]

where $\mathrm{P}$ is the probability, $w$ is the binary variable of market participation, $\Phi$ is the cumulative normal distribution, $x$ is the vector of household characteristics that includes an indicator of access to social grants and $\gamma$ are the coefficients to be estimated.

The level of maize market participation, $y^{*}$, assumed to have a truncated normal distribution with parameters that vary freely from those in the probit model was estimated as follows:

$y^{*}=x \beta+\varepsilon_{i}$

[Eqn 2]

where $y^{*}$ represents the quantity of maize output sold in tons; $x$ is the vector of household characteristics that included indicators of grant access and dependency, $\varepsilon_{i}$ is the error term and $\beta^{\prime}$ s are parameters that were estimated.

A log-likelihood test was done to justify the use of the doublehurdle model over the Tobit model. Based on the loglikelihood values obtained from a separate estimation of the probit, truncated regression and Tobit models, the likelihood ratio statistic $(\lambda)$ was computed as follows:

$\lambda=2\left[\mathrm{LL}_{\text {probit }}+\mathrm{LL}_{\text {trunc }}-\mathrm{LL}_{\text {tobit }}\right]$

[Eqn 3]

where $\mathrm{LL}_{\text {probit' }} \mathrm{LL}_{\text {trunc }}$ and $\mathrm{LL}_{\text {tobit }}$ are the likelihood values from the probit, truncated regression and Tobit models, respectively. The test statistic has a $\chi^{2}$ distribution with degrees of freedom equal to the number of independent variables (including the intercept) (Greene 2003). The Tobit model is rejected in favour of the double-hurdle model if $\lambda$ exceeds the appropriate $\chi^{2}$ critical value, as was the case in this study (Burke 2009; Mabuza et al. 2014). 
As social grants are not a random intervention but a targeted intervention, it was suspected that the estimated model may be affected by selection bias. Selection bias may occur because farmers with higher intrinsic motivation and ability are more likely to have more income and assets, meaning that they are less likely to qualify to benefit from social grants. These motivated farmers are also more likely to participate in the maize market, resulting in selection bias. The probit model (Equation 1) was first estimated using the Heckman selection probit model (heckprob command in Stata), with access to social grants as the selection variable. The likelihood ratio test of independent equations was done to indicate if there was evidence of selection bias at the conventional $10 \%$ significance level. The test showed that there was no evidence of selection bias.

Moreover, Hausman test (Hausman 1978) was conducted to test for potential endogeneity of dependency on social grants in the model. This is because it is possible that causality might flow from market participation to dependency on social grants, as increased market participation results in increased farm income. The increased farm income would result in decreased dependency on social grants, ceteris paribus. The test was implemented by firstly regressing social grants dependency on the exogenous explanatory variables as follows:

$G D_{i}=z \gamma+u_{i}$

[Eqn 4]

where GD means dependency on social grants, $z$ is the vector of exogenous variables, $\gamma$ are the estimated coefficients and $u_{i}$ is the residual term.

The second step involved obtaining the residuals $\left(u_{i}\right)$ and then adding these residuals in the truncated regression equation (Equation 2). A statistically significant estimated coefficient of the residuals would mean endogeneity problems, while a statistically insignificant estimate (as was the case in this study) means no evidence of the endogeneity problem. The potential endogeneity of other variables such as prices and assets (Boughton et al. 2007; Mather et al. 2013), was not tested. Therefore, the estimated coefficients of these variables should be interpreted as associations, not as causality relationships.

\section{Ethical considerations}

All procedures performed in studies involving human participants were in accordance with the ethical standards of the Human and Social Sciences Research Ethics Committee of the University of KwaZulu-Natal (Reference number: HSS/0027/015D) and with the 1964 Helsinki Declaration and its later amendments or comparable ethical standards.

\section{Empirical results and discussions Descriptive statistics}

Table 2 shows the socio-economic characteristics of the respondents per their market participation status. The moderate proportion of maize market participators is comparable to other studies in rural South Africa. For example, Biénabe and Vermeulen (2011) reported a figure of $43 \%$ maize market participants in the Limpopo province.

Table 2 also shows some significant differences in wealth and institutional or organisational support between market participants and non-participants. Households participating in the maize market had bigger family sizes, were richer in assets and had more farm income. The market participants had more access to extension and information and were members of associations. Moreover, the market participants had less access to social grants and received less of their income from social grants, that is, they were less dependent on social grants. The table also shows that the market participants were nearer to markets, had higher maize output and were more productive in maize production.

\section{Empirical results}

Table 3 presents the results from the double-hurdle model. The likelihood ratio test of independent equations found no evidence of selection bias $\left(\chi^{2}[1]=0.37, p=0.54\right)$ at the conventional $10 \%$ significance level. The Hausman tests found no evidence of endogeneity between social grant dependency and market participation level $(F=0.49, p=$ 0.48 ) at the conventional $10 \%$ significance level. The doublehurdle model was chosen instead of the Tobit model because the log-likelihood test showed that it performed better than the Tobit model $\left(\lambda=622\right.$ exceeded the $\chi^{2}$ [23] critical value $=$ 35). This implies that the decision to participate in the market and the volume of maize sold in the market are governed by separate processes. The probit model correctly predicted $80 \%$ of the participation outcomes, and the Wald test highly rejected the hypothesis that all regression coefficients are jointly equal to zero. This indicates that the model fits the data reasonably well.

Table 3 shows that increasing dependency on social grants (GRANTPROP) was associated with decreasing probability of participation in the maize market. In other words, households who depended more on social grants were less likely to decide to enter the maize produce market compared with those who depended less on social grants. This result, coupled with the insignificant estimated coefficient of access to social grants (GRANTACESS) in the market participation model, imply that the decision to enter the maize market is not dependent on access to social grants per se but on the importance of social grant income to total household income. This suggests that the social grant-dependent households are more subsistent, mostly producing for themselves and producing less marketable surplus. This is in line with Mabugu et al. (2014), who found that social grant recipient households were more likely to be subsistent-oriented as the extra income from subsistence farming activities is generally minimal and thus does not disqualify the household from accessing the social grants.

The significant and negative estimated coefficient of access to social grants (GRANTACESS) in the maize marketed model 
TABLE 2: Socio-economic characteristics of the sampled households according to maize market participation status $(n=774)$.

\begin{tabular}{|c|c|c|c|c|}
\hline Variable name & All sample $(n=774)$ & Marketers $(n=441)$ & Non-marketers $(n=333)$ & $T$ tests $\left(\chi^{2}\right.$ tests) \\
\hline Age & 56 & 56 & 57 & -1.05 \\
\hline Gender & 0.47 & 0.49 & 0.45 & 0.77 \\
\hline Education level & 4.67 & 4.84 & 4.41 & 1.44 \\
\hline Household size & 7.04 & 7.27 & 6.82 & $1.77^{*}$ \\
\hline Land size & 1.93 & 2.15 & 1.80 & 0.97 \\
\hline Livestock size & 3.54 & 4.60 & 2.55 & 1.45 \\
\hline Access to grants & 0.85 & 0.80 & 0.91 & $18.7^{* * *}$ \\
\hline Off-farm income & 40204 & 40790 & 40979 & -0.09 \\
\hline Farm income & 6553 & 7343 & 5249 & $2.47 * *$ \\
\hline Grant income & 16587 & 13552 & 20068 & $-6.82 * * *$ \\
\hline Proportion of grant income & 0.38 & 0.31 & 0.45 & $-8.16 * * *$ \\
\hline Maize price & 1484 & 1674 & 1243 & $10.09 * * *$ \\
\hline Maize output & 0.516 & 0.710 & 0.316 & $5.27 * * *$ \\
\hline Access to market & 0.20 & 0.25 & 0.16 & $9.07 * * *$ \\
\hline Group membership & 0.42 & 0.45 & 0.38 & $4.39 * *$ \\
\hline Access to credit & 0.36 & 0.37 & 0.35 & 0.32 \\
\hline Extension & 0.57 & 0.68 & 0.42 & $55.34 * * *$ \\
\hline Information sources & 2.28 & 2.36 & 2.14 & $2.80 * * *$ \\
\hline Training & 0.41 & 0.39 & 0.43 & 1.22 \\
\hline Distance to market & 24 & 20 & 33 & $5.23 * * *$ \\
\hline Farming experience & 19 & 19 & 19 & 0.24 \\
\hline Employment status & 0.20 & 0.23 & 0.22 & 0.01 \\
\hline Business ownership & 0.08 & 0.12 & 0.05 & $11.02 * * *$ \\
\hline Irrigation access & 0.46 & 0.54 & 0.35 & $28.23 * * *$ \\
\hline Harry Gwala & 0.42 & 0.37 & 0.47 & $8.49 * * *$ \\
\hline Umzinyathi & 0.24 & 0.28 & 0.17 & $12.61 * * *$ \\
\hline Uthukela & 0.19 & 0.11 & 0.34 & $64.02 * * *$ \\
\hline Quantity of maize sold & 0.278 & - & - & - \\
\hline Proportion of maize sold & 0.45 & - & - & - \\
\hline
\end{tabular}

$* * *, * *$ and $*$, significant at $1 \%, 5 \%$ and $10 \%$ levels, respectively.

suggests that households with access to social grants sell less maize quantities in the market than those without, ceteris paribus. This result implies that access to social grants, instead of helping households overcome the variable transaction costs, decreases incentives to sell more maize produce by the market participants. A plausible explanation for this result is that social grant recipient households are producing mostly for subsistence purposes, and enter the maize market targeting to raise a certain amount of income needed to maintain a desired consumption level. Therefore, increasing household income through social grants decreases the need to sell more maize produce in the market. This result applies to both the highly and lowly social grant-dependent households, as dependency on social grants (GRANTPROP) was not significant in the maize supply model.

The results suggest that, while social transfers may increase the productive capacity of rural households, as has been reported in the literature (e.g. Boone et al. 2013; Covarrubias et al. 2012; Todd et al. 2010), they are dis-incentives for these households to commercialise their farming activities. This result is consistent with studies such as those of Radel et al. (2016) and Todd et al. (2010) who found that beneficiaries of cash transfers in Mexico were more likely to engage in semi-subsistence farming, even though they harvested more on average. The results support evidence from descriptive and anecdotal reports in South Africa (e.g. Aliber \& Hart 2009; Mabugu et al. 2014), describing a potential dis-incentive effect of social grants on smallholder market participation.

Age (AGE) was positively related to market participation, implying that older farmers were more likely to participate in the market. This could be because older farmers would have developed greater market contacts and trust that would allow them to trade at lower transaction costs. This result is contrary to the majority of literature (e.g. Alene et al. 2008; Geoffrey et al. 2013), which has reported that increasing age is associated with decreasing chances of market participation as older farmers are less receptive to new ideas and are more risk-averse than younger farmers. The implication here is that the effect of increased contacts and/or networks dominates the risk aversion associated with older farmers, resulting in a positive relationship between age and market participation.

The negative estimated coefficient of GENDER implies that female-headed households are more likely to sell more maize quantities in the market than male-headed households. This result is inconsistent with expectations and a number of 
TABLE 3: The impact of social grants dependency on maize market participation: The double-hurdle model results $(N=774)$.

\begin{tabular}{|c|c|c|c|c|}
\hline \multirow[t]{2}{*}{ Variables } & \multicolumn{2}{|c|}{ Market participation } & \multicolumn{2}{|c|}{ Maize marketed } \\
\hline & Coefficient & Standard error & Coefficient & Standard error \\
\hline Age & $0.012 * *$ & 0.005 & 0.049 & 0.071 \\
\hline Gender & -0.021 & 0.117 & $-6.021 * * *$ & 2.408 \\
\hline Education level & $0.037 * *$ & 0.016 & -0.136 & 0.213 \\
\hline Household size & 0.005 & 0.017 & 0.275 & 0.222 \\
\hline Land size & $0.122 * *$ & 0.055 & $1.859 * *$ & 0.918 \\
\hline Livestock size & -0.002 & 0.004 & 0.001 & 0.021 \\
\hline Asset value & $0.275 * * *$ & 0.084 & -0.926 & 1.238 \\
\hline Maize output & $0.676 * * *$ & 0.108 & $3.493 * * *$ & 0.783 \\
\hline Maize price & $0.001 * * *$ & 0.000 & $0.002 * *$ & 0.001 \\
\hline Access to grants & 0.277 & 0.210 & $-6.144 * *$ & 2.937 \\
\hline Proportion of grant income & $-1.450 * * *$ & 0.323 & 2.003 & 4.730 \\
\hline Extension & $0.325 * * *$ & 0.122 & 2.912 & 2.061 \\
\hline Information sources & 0.068 & 0.059 & - & - \\
\hline Group membership & -0.111 & 0.140 & $3.476^{*}$ & 1.953 \\
\hline Access to credit & -0.076 & 0.120 & -1.892 & 1.680 \\
\hline Training & $0.244 *$ & 0.128 & 1.288 & 1.567 \\
\hline Distance to market & $-0.009 * * *$ & 0.002 & $0.051 * * *$ & 0.018 \\
\hline Farming experience & 0.005 & 0.005 & 0.016 & 0.063 \\
\hline Employment status & $-0.411 * * *$ & 0.157 & -1.750 & 2.225 \\
\hline Business ownership & 0.300 & 0.217 & $5.108^{*}$ & 2.910 \\
\hline Umzinyathi & $0.510 * * *$ & 0.161 & -0.311 & 2.344 \\
\hline Uthukela & $-0.493 * * *$ & 0.158 & $4.736^{*}$ & 2.477 \\
\hline Umkhanyakude & $1.683 * * *$ & 0.267 & -2.166 & 2.407 \\
\hline Constant & $-4.944 * * *$ & 1.022 & -16.457 & 15.570 \\
\hline$\Sigma$ & - & - & $2.794 * * *$ & 0.435 \\
\hline
\end{tabular}

$* * *, * *$ and $*$, significant at $1 \%, 5 \%$ and $10 \%$ levels, respectively.

Note: Wald $\chi^{2}(23)=231.42 * * * ;$ Pseudo $R^{2}=0.35 ; \%$ Correctly classified $=80$

studies in the past (e.g. Boughton et al. 2007; Geoffrey et al. 2013; Hlongwane et al. 2014). The expectation was that maleheaded households would be more likely to sell more because of their advantages in bargaining, negotiating and enforcing contracts. The result, which is in line with a few studies such as Boniphace, Fengying and Chen (2014), suggests that female-headed households are not at risk of exclusion in the market for staples such as maize. While female-headed households may have disadvantages in the male-dominated high-value cash crop markets (Boughton et al. 2007), the result implies that female-headed households have advantages in the low-value food crop markets.

The results show that households headed by more educated heads (EDUCAT) were more likely to participate in the maize market. This result is consistent with a priori expectations and other studies (e.g. Geoffrey et al. 2013). The explanation is that more educated people are able to understand and interpret market information better, resulting in less transaction costs. However, once the decision to participate in the market is made, education level had no significant impact. This implies that while education helps reduce fixed transaction costs such as search costs, it has no significant impact on the variable transaction costs such as transportation costs.

Increasing farm size (LAND) was found to be associated with higher chances of selling maize as well as selling more quantities of maize. This is because land is an important production factor that enables households to produce a surplus for the market. The result is also consistent with previous market participation studies (e.g. Alene et al. 2008; Boniphace et al. 2014; Boughton et al. 2007; Jagwe, Machethe \& Ouma 2010; Makhura et al. 2001) that have highlighted the critical role that access to land plays in motivating smallholder farmers to produce for the markets. Increasing asset value (ASSETS) was also found to be associated with increased likelihood of market participation. This is in line with the literature (e.g. Barrett \& Swallow 2006; Boughton et al. 2007) which has shown the importance of assets in enabling smallholder farmers to produce a surplus necessary for participating in markets as sellers. Moreover, asset ownership facilitates access to credit and technology adoption, and wealthier households are more likely to undertake riskier activities such as market participation because of their capacity to bear risks.

The results also demonstrate the importance of increasing production levels (MZOUTPUT) in market participation. The households who produced more maize were more likely to participate in the market than households producing less. After the decision to participate in the market was made, those with higher output were likely to sell more. The explanation is that as market participation requires the smallholder farmers to produce a marketable surplus, those households with higher production levels are likely to have more than enough for family consumption. This result is in agreement with other market participation studies (e.g. Bwalya et al. 2013; Geoffrey et al. 2013; Komarek 2010). 
Consistent with a priori expectations informed by economic theory and literature (e.g. Boughton et al. 2007; Jagwe et al. 2010; Key et al. 2000; Komarek 2010), the study found a positive relationship between the maize producer price (MZPRICE) and both the decision to sell maize and quantity sold. This indicates that the producer price provides incentives for households to participate and sell more maize in the market, implying rational economic behaviour by smallholder farmers. However, it must be noted that many smallholder farmers sell their produce right after harvest to satisfy their immediate cash requirements, and their capacity to wait and take advantage of higher prices is low. As such, this result should be interpreted as indicating that smallholder farmers are responsive to price changes, at least in the short term.

The results also show that access to extension (EXTENSION) was associated with increased chances of participating in the market. Extension officers remain the main sources of agricultural market information among the rural households, and contact with extension agents keeps the farmers updated with information regarding market locations, prices and potential buyers and/or sellers. Training (TRAINING) was also found to have a positive impact on the decision to participate in the market, implying that focussed farmer training may increase the chances of households participating in the market. While group membership (GROUP) was insignificant in the market participation model, it was significant in the maize supply model. This implies that group membership played a less significant role as a channel of information exchange but a significant role as a means of sharing variable costs such as transport costs among the sampled households. This is consistent with previous studies (e.g. Alene et al. 2008).

As expected, and in line with the literature (Bwalya et al. 2013; Hlongwane et al. 2014), farmers who stay further away from the markets (MKTDIST) had less chances of participating in the market than those who stay nearer. This is because market information published in formal channels, such as newspapers, is not very relevant to farmers in rural areas as these channels mainly report national figures. The isolated nature of rural areas means that the local market situation could be very different from the national situation. As such, farmers have to physically go to the local market places to gather such relevant information. The insignificant estimated information access variable (INFORM) confirms this to be the case in the study areas, as increasing diversity of information sources was not very useful as the information may not be contextually relevant. Consequently, the farmers located further from the market incur higher search costs than those nearer to the market.

However, once the farmer has decided to participate, increasing distance was associated with increasing quantity of maize produce sold. This indicates that the higher transport costs that the farmers who stay farther incur make them strive to meet a certain supply threshold to make profits. The farmers who stay farther sell more to make the same amount of money compared to the ones who stay closer because of the additional transaction costs. This is in line with other studies (e.g. Boughton et al. 2007). Households where the heads have non-farm employment (EMPLOYED) were less likely to participate than those where heads were unemployed. This may be because households where heads are employed depend on wages for income and only practice farming for subsistence. The results also show that owners of non-farm businesses (BUSINESS) sold more in the market than non-business owners. This may be because the nonfarm business owners have established more contacts or networks, resulting in declining transaction costs.

The significant district dummies show that farming households from both Umkhanyakude and Umzinyathi were more likely to participate in the market than those in Harry Gwala district. In contrast, smallholder farmers in Uthukela district were less likely to participate compared to the Harry Gwala smallholder farmers. These district dummies capture the political, social and agro-climatic variations in these areas that impact on market participation but were not captured in the model. A possible explanation of the higher maize participation rates in Umkhanyakude than in Harry Gwala districts is that the Umkhanyakude district has higher maize potential (i.e. higher chances of producing a surplus) as well as near-by market centres for farmers to sell their maize. The culture of selling maize seems to have been inculcated among smallholder farmers in Umkhanyakude, particularly in and around the Jozini town. While Harry Gwala district has equally high potential in maize production, particularly in the Ubuhlebezwe local municipality, access to the market is a major problem because of poor roads. For example, the main road joining one of the high potential smallholder maize producing areas of Hlokozi and the nearest main town Ixopo is mostly a gravel road, which becomes impassable during the rainy season.

A plausible explanation for the higher market participation rates in the Umzinyathi district than in Harry Gwala is that because the high temperatures and low rainfall make it difficult for many households to produce crops, then for those who can produce a surplus there is a ready market from the surrounding communities. The lower maize market participation rates in the Uthukela district than in the Harry Gwala district may be because the rural areas in Uthukela are isolated and far from bigger urban centres.

\section{Conclusion}

Using the double-hurdle model on a sample of 774 maize producing households, the study concluded that social grants reduce the incentives of smallholder farmers to commercialise their production activities. The study results indicated that dependency on social grants was associated with decreased chances of maize market participation. Moreover, households with access to social grants were likely to sell less maize quantities compared with households with no access to social grants. In other words, the smallholder farmers who have access to and are highly dependent on social grants are less 
likely to be market-oriented, and to sell less maize on the market, respectively.

The fact that social grant-dependent households were more likely to produce only for subsistence purposes and depend on social grants for income suggests that social grants were spilling over to the undeserving household members, reducing recipient households' incentives to engage in income-generating farming activities. The study findings suggest that the implementation of social welfare programmes among developing countries, such as South Africa, may have negative implications on the drive to increase commercialisation levels of smallholder farmers. In South Africa, this presents challenges in meeting the government's target of establishing 300000 additional market-oriented smallholder producers by 2020. While this study is not advocating for the removal of social support from poor households, it highlights the need to re-look at how these two interventions (social grants and smallholder commercialisation) may be synchronised in such a way that they complement each other as options for rural livelihoods. A policy option is to offer part of the grant as 'in-kind support', which is specific to the intended individual beneficiary, instead of cash which is fungible. This will help in reducing spillover effects and dis-incentives of recipient households to engage in economic activities.

The study results also suggest that female-headed households may be successfully included in the market for staples. Although there are concerns elsewhere that women are likely to remain subsistence farmers because of their exclusion from the market, this study indicates that there is potential of reversing that trend if women are encouraged to produce and sell staples such as maize. The study results also imply that policies aimed at reducing both fixed and variable transaction costs (such as improved road infrastructure and institutional support like extension, training and organising farmers into groups) should be prioritised to increase both rates and levels of smallholder participation in the maize markets.

\section{Acknowledgements Competing interests}

The authors declare that they have no financial or personal relationships that may have inappropriately influenced them in writing this article.

\section{Authors' contributions}

This article was conceived by S.S. He designed the data collection tools and coordinated the data collection process. S.S. also analysed the data and wrote the initial draft of this article. M.M. and E.W. contributed valuable supervision, guidance, insights and comments on every stage (project conception, data collection, analysis and write-up) of producing this article. They also edited different draft versions of this article.

\section{References}

Abel, M., 2013, Unintended labour supply effects of cash transfer programmes: Evidence from South Africa's old age pension, University of Cape Town, Cape Town.

Agwu, N.M., Anyanwu, C.I. \& Mendie, E.I., 2012, 'Socio-economic determinants of commercialization among smallholder farmers in Abia State, Nigeria', Greener Journal of Agricultural Sciences 2, 392-397.

Akpalu, W., Hassan, R.M. \& Ringler, C., 2010, Climate variability and maize yield in South Africa. IFPRI Research Brief 15-10, International Food Policy Research Institute, Washington, DC.

Alene, A.D., Manyong, V.M., Omanya, G., Mignouna, H.D., Bokanga, M. \& Odhiambo, G., 2008, 'Smallholder market participation under transactions costs: Maize supply and fertilizer demand in Kenya', Food Policy 33, 318-328. https://doi. supply and fertilizer demand in Keny
org/10.1016/j.foodpol.2007.12.001

Aliber, M. \& Hall, R., 2012, 'Support for smallholder farmers in South Africa: Challenges of scale and strategy', Development Southern Africa 29, 548-562. https://doi.org/ 10.1080/0376835X.2012.715441

Aliber, M. \& Hart, T.G.B., 2009, 'Should subsistence agriculture be supported as a strategy to address rural food insecurity?', Agrekon 48, 434-458. https://doi.org/ 10.1080/03031853.2009.9523835

Barrett, C.B., 2006, Food aid's intended and unintended consequences. Background paper for FAO State of Food and Agriculture 2006, Cornell University, Ithaca, NY.

Barrett, C.B. 2008. 'Smallholder market participation: Concepts and evidence from eastern and southern Africa', Food Policy 33, 299-317. https://doi.org/10.1016/j. foodpol.2007.10.005

Barrett, C.B. \& Swallow, B.M., 2006, 'Fractal poverty traps', World Development 34 1-15. https://doi.org/10.1016/j.worlddev.2005.06.008

Barrientos, A., 2012, 'Social transfers and growth: What do we know? What do we need to find out?' World Development 40, 11-20. https://doi.org/10.1016/j. worlddev.2011.05.012

Bastagli, F., Hagen-Zanker, J., Harman, L., Barca, V., Sturge, G. \& Schmidt, T., 2016, Cash transfers: What does the evidence say? A rigorous review of programme impact and the role of design and implementation features, Overseas Development Institute, London.

Bertrand, M., Mullainathan, S. \& Miller, D., 2003, 'Public policy and extended families: Evidence from pensions in South Africa', World Bank Economic Review 17, 27-50. https://doi.org/10.1093/wber/lhg014

Bezu, S. \& Holden, S., 2008, 'Can food-for-work encourage agricultural production?' Food Policy 33, 541-549. https://doi.org/10.1016/j.foodpol.2008.06.004

Biénabe, E. \& Vermeulen, H., 2011, 'Improving smallholders' market participation: Insights from a business scheme for maize in Limpopo Province, South Africa', Development Southern Africa 28, 493-507. https://doi.org/10.1080/0376835X. 2011.605567

Binger, B.R. \& Hoffman, E., 1998, Microeconomics with calculus, Addison-Wesley Publishers Inc., Boston, MA.

Boniphace, N.S., Fengying, N. \& Chen, F., 2014, 'An analysis of factors affecting smallholder rice farmers' level of sales and market participation in Tanzania: Evidence from national panel survey data 2010-2011', Journal of Economics and Sustainable Development 5, 185-204.

Boone, R., Covarrubias, K., Davis, B. \& Winters, P., 2013, 'Cash transfer programs and agricultural production: The case of Malawi', Agricultural Economics 44, 365-378. https://doi.org/10.1111/agec.12017

Boughton, D., Mather, D., Barrett, C.B., Benfica, R., Abdula, D., Tschirley, D. et al., 2007 'Market participation by rural households in a low-income country: An assetbased approach applied to Mozambique', Faith and Economics 50, 64-101.

Burke, W.J., 2009, 'Fitting and interpreting Cragg's tobit alternative using Stata', The Stata Journal 9, 584-592.

Bwalya, R., Mugisha, J. \& Hyuha, T., 2013, 'Transaction costs and smallholder household access to maize markets in Zambia', Journal of Development and Agricultural Economics 8, 328-336. https://doi.org/10.5897/JDAE12.134

Carter, M.R. \& Barrett, C.B., 2006, 'The economics of poverty traps and persistent poverty: An assets-based approach', Journal of Development Studies 42, 178-199. https://doi.org/10.1080/00220380500405261

Chikazunga, D., 2013, 'Determinants of smallholder farmers' participation in modern food markets: The case of tomato supply chains in Limpopo', in S. Greenberg (ed.), Smallholder and agro-food value chains in South Africa: Emerging practices, emerging challenges, pp. 15-22, Institute of Poverty, Land and Agrarian Studies emerging challenges,
(PLAAS), Cape Town.

Covarrubias, K., Davis, B. \& Winters, O., 2012, 'From protection to production: Productive impacts of the Malawi social cash transfer scheme', Journal of Development Effectiveness 4, 50-77. https://doi.org/10.1080/19439342.2011.641995

Cragg, J.G., 1971, 'Some statistical models for limited dependent variables with application to the demand for durable goods', Econometrica 39, 829-844. https:// doi.org/10.2307/1909582

D'Haese, M., Vink, N., Nkunzimana, T., Van Damme, E., Van Rooyen, J., Remaut, A.-M et al., 2013, 'Improving food security in the rural areas of KwaZulu-Natal province, South Africa: Too little, too slow', Development Southern Africa 30, 468-490. https://doi.org/10.1080/0376835X.2013.836700

De Janvry, A., Fafchamps, M. \& Sadoulet, E., 1991, 'Peasant household behaviour with missing markets: Some paradoxes explained', The Economic Journal 101 1400-1417. https://doi.org/10.2307/2234892

Department of Agriculture, Forestry and Fisheries (DAFF), 2012, Strategic plan for smallholder support, DAFF, Pretoria. 
Department of Economic Development (DED), 2011, The New Growth Path Framework. DED, Pretoria, viewed 25 August 2015, from http://www.economic. gov.za/communications/publications/new-growth-path-series

Devereux, S., 2001, Social pensions in Namibia and South Africa, IDS Discussion Paper 379, Institute of Development Studies, Brighton.

Dow, W. \& Norton, E., 2003, 'Choosing between and interpreting the heckit and twopart models for corner solutions', Health Services and Outcomes Research Methodology 4, 5-18. https://doi.org/10.1023/A:1025827426320

FAO, 2016, Strengthening coherence between agriculture and social protection to combat poverty and hunger in Africa: Framework for analysis and action, FAO, Rome.

Geoffrey, S.K., Hillary, B.K., Lawrence, K.K. \& Mary, M.C., 2013, 'Determinants of market participation among small-scale pineapple farmers in Kericho county, Kenya', Journal of Economics and Sustainable Development 4, 59-66.

Gibson, J., 2015, 'Expanded social protection may do more harm than good: A pessimistic review', Asia \& the Pacific Policy Studies 2, 652-659. https://doi. org/10.1002/app5.106

Goetz, S.J., 1992, 'A selectivity model of household food marketing behaviour in SubSaharan Africa', American Journal of Agricultural Economics 74, 444-452. https:// Sai.org/10.2307/1242498
doing

Greene, W.H., 2003, Econometric analysis, Prentice-Hall, Inc., Upper Saddle River, NJ.

Hausman, J.A., 1978, 'Specification tests in econometrics', Econometrica 46, 12511271. https://doi.org/10.2307/1913827

Hazell, P., Poulton, C., Wiggins, S. \& Dorward, A., 2010, 'The future of small farms: Trajectories and policy priorities', World Development 38, 1349-1361. https://doi. org/10.1016/j.worlddev.2009.06.012

Hlongwane, J.J., Ledwaba, L.J. \& Belete, A., 2014, 'Analyzing the factors affecting market participation of maize farmers: A case study of small-scale farmers in greater Giyani local municipality of the Mopani
African Journal of Agricultural Research 9, 895-899.

Holloway, G., Barrett, C.B. \& Ehui, S., 2005, 'Bayesian estimation of the double hurdle model in the presence of fixed costs', Journal of International Agricultural Trade and Development 1, 17-28. https://doi.org/10.2139/ssrn.2633551

Jagwe, J., Machethe, C. \& Ouma, E., 2010, 'Transaction costs and smallholder farmers' participation in banana markets in the Great Lakes Region of Burundi, Rwanda and the Democratic Republic of Congo', African Journal of Agricultural and Resource Economics 6, 302-317.

Jari, B. \& Fraser, G.C.G., 2013, 'An analysis of institutional and technical factors influencing agricultural marketing amongst smallholder farmers in the Kat River Valley, Eastern Cape Province, South Africa', African Journal of Agricultural Marketing 1, 16-23.

Key, N., Sadoulet, E. \& De Janvry, A., 2000, 'Transactions costs and agricultural household supply response', American Journal of Agricultural Economics 82, 245-259. https://doi.org/10.1111/0002-9092.00022

Khumalo, L.D., 2013, 'Big business for small farmers: The case of Venda avocado growers', in S. Greenberg (ed.), Smallholder and agro-food value chains in South Africa: Emerging practices, emerging challenges, pp. 29-37, Institute of Poverty, Land and Agrarian Studies (PLAAS), Cape Town.

Klasen, S. \& Woolard, I., 2008, 'Surviving unemployment without state support: Unemployment and household formation in South Africa', Journal of African Economies 18, 1-51. https://doi.org/10.1093/jae/ejn007

Komarek, A., 2010, 'The determinants of banana market commercialisation in Western Uganda', African Journal of Agricultural Research 5, 775-784.

Lentz, E., Barrett, C.B. \& Hoddinott, J., 2005, Food aid and dependency: Implication for emergency food security assessments, IFPRI Discussion Paper No. 12-2, IFPRI, Washington, DC.

Mabugu, R., Chitiga, M., Fofana, I., Abidoye, B. \& Mbanda, V., 2014, 'Assessing the general equilibrium effects of social grants in South Africa', 17th Annual Conference on Global Economic Analysis "New Challenges in Food Policy, Trade and Economic Vulnerability", Dakar, Senegal, June 18-20, 2014.

Mabuza, M.L., Ortmann, G. \& Wale, E., 2014, 'Effects of transaction costs on mushroom producers' choice of marketing channels: Implications for access to agricultural markets in Swaziland', South African Journal of Economic and Management Sciences 2, 207-219.
Makhura, M.T., 2001, 'Overcoming transactions costs barriers to market participation of smallholder farmers in the Northern Province of South Africa', PhD thesis, University of Pretoria.

Makhura, M.T., Kirsten, J. \& Delgado, C., 2001, 'Transaction cost and smallholder participation in the maize market in the Northern Province of South Africa", Seventh Eastern and Southern Africa Regional Maize Conference, Nairobi, February 11-15, 2001.

Maluccio, J.A., 2010, 'The impact of conditional cash transfers on consumption and investment in Nicaragua', The Journal of Development Studies 46, 14-38. https:// doi.org/10.1080/00220380903197952

Mather, D., Boughton, D. \& Jayne, T.S., 2013, 'Explaining smallholder maize marketing in southern and eastern Africa: The roles of market access, technology and household resource endowments', Food Policy 43, 248-266. https://doi.org/ 10.1016/j.foodpol.2013.09.008

Mcfadden, D., 1974, 'The measurement of urban travel demand', Journal of Public Economics 3, 303-328. https://doi.org/10.1016/0047-2727(74)90003-6

National Planning Commission (NPC), 2012, Our future-make it work: National Development Plan 2030, NPC, Pretoria, viewed 09 October 2013, from http:// www.info.gov.za/issues/national-development-plan

Ndoro, J.T., Mudhara, M. \& Chimonyo, M., 2014, 'Cattle commercialization in rura South Africa: Livelihood drivers and implications for livestock marketing extension', Journal of Human Ecology 45, 207-221.

Omamo, S.W., 1998, 'Farm-to-market transaction costs and specialisation in smallscale agriculture: Explorations with a non-separable household model', The Journal of Development Studies 35, 152-163. https://doi.org/10.1080/00220389808422568

Ortmann, G.F. \& King, R.P., 2010, 'Research on agri-food supply chains in Southern Africa involving small-scale farmers: Current status and future possibilities', Agrekon 49, 397-417. https://doi.org/10.1080/03031853.2010.526428

Radel, C., Schmook, B., Haenn, N. \& Green, L., 2016, 'The gender dynamics of conditional cash transfers and smallholder farming in Calakmul, Mexico', Women's Studies International Forum. https://doi.org/10.1016/j.wsif.2016.06.004

Samson, M., Lee, U., Ndlebe, A., Quene, K.M., van Niekerk, I., Gandhi, V., et al., 2004, The social and economic impact of South Africa's social security system, Economic Policy Research Institute, Cape Town.

Sebatta, C., Mugisha, J., Katungi, E., Kashaaru, A. \& Kyomugisha, H., 2014, 'Smallholder farmers' decision and level of participation in the potato market in Uganda', Modern Economy 5, 895-906. https://doi.org/10.4236/me.2014.58082

Senyolo, G.M., Chaminuka, P., Makhura, M.N. \& Belete, A., 2009, 'Patterns of access and utilization of output markets by emerging farmers in South Africa: A factor analysis approach', African Journal of Agricultural Research 4, 208-214.

South Africa Social Security Agency (SASSA), 2014, First quarter statistical report on social grants, SASSA, Pretoria.

Stats SA, 2012, Census 2011 Municipal report - KwaZulu-Natal, Statistics South Africa, Pretoria, viewed 09 March 2015, from http://www.statssa.gov.za/Census2011/ Products/KZN_Municipal_Report.pdf

Tirivayi, N., Knowles, M. \& Davis, B., 2016, 'The interaction between social protection and agriculture: A review of evidence', Global Food Security 10, 52-62. https:// doi.org/10.1016/j.gfs.2016.08.004

Todd, J.E., Winters, P.C. \& Hertz, T., 2010, 'Conditional cash transfers and agricultural production: Lessons from the Oportunidades experience in Mexico', The Journa of Development Studies 46, 39-67. https://doi.org/10.1080/00220380903197945

Tshuma, M.C., 2012, 'A review of the poverty and food security issues in South Africa: Is agriculture the solution?', African Journal of Agricultural Research 7, 4010-4020. https://doi.org/10.5897/AJAR12.056

Van der Heijden, T. \& Vink, N., 2013, 'Good for whom? Supermarkets and small farmers in South Africa: A critical review of current approaches to increasing farmers in South Africa: A critical review of current approaches to increasing access to mode

Von Braun, J., 1995, 'Agricultural commercialization: Impacts on income and nutrition and implications for policy', Food Policy 20, 187-202. https://doi.org/10.1016/ 0306-9192(95)00013-5

White, H. \& Killick, T., 2001, African poverty at the millennium, causes, complexities and challenges. Strategic Partnership with Africa, World Bank, Washington, DC. https://doi.org/10.1596/0-8213-4867-1 